\begin{tabular}{l|c|c}
\hline Jurnal Penelitian Farmasi Herbal & Vol. 2 No. 1 & Edition: May- October 2019 \\
\hline \multirow{2}{*}{ Received: 26 October 2019} & http://ejournal.delihusada.ac.id/index.php/JPFH & Accepted: 31 October 2019 \\
\cline { 2 - 3 } & Revised: 30 October 2019 & Act9
\end{tabular}

\title{
UJI EFEKTIVITAS ANTIDIABETES KOMBINASI EKSTRAK DAUN MENIRAN (Phyllanthus niruri L.) Dan KELOPAK BUNGA ROSELLA (Hibiscus sabdariffa L.) PADA TIKUS JANTAN PUTIH
}

\author{
Herviani Sari, Vera Estefania Kaban, Friska Raulina Situmorang, Firdaus Fahdi \\ Institut Kesehatan Deli Husada, Jl. Besar No. 77 Deli Tua \\ e-mail: herviani.sari10@gmail.com
}

\begin{abstract}
Purpose: To determine the effect of decreasing blood glucose levels in white rats using a combination of meniran and rosella compared to glibenclamide. Method: This research was carried out experimentally. Simplicia of meniran leaves and rosella macerated using $80 \%$ ethanol. The research used 21 rats that were induced by alloxan and divided into 7 groups and all compared using glibenclamide.Group 1 (negative control) CMC Na 1\%, group 2 (positive control) glibenclamide dose $0.45 \mathrm{mg} / \mathrm{kgMB}$, group 3 single roselle extract dose $130 \mathrm{mg} / \mathrm{kgMB}$, group 4 single meniran leaf extract dose $200 \mathrm{mg} / \mathrm{kgMB}$, group 5 combination of meniran leaf extract dose of $100 \mathrm{mg} / \mathrm{kgMB}$ and rosella extract dose of $65 \mathrm{mg} / \mathrm{kgMB}$, group 6 combination of meniran leaf extract dose of $200 \mathrm{mg} / \mathrm{kgMB}$ and rosella extract dose of $130 \mathrm{mg} / \mathrm{kgMB}$, and group 7 meniran leaf extract combination dose $400 \mathrm{mg} / \mathrm{kgMB}$ and rosella extract dose $195 \mathrm{mg} / \mathrm{kgMB}$. Result; The results showed that rats had hyperglycemia after being induced by alloxan.Data were analyzed using one way ANOVA method followed by $L S D$ and tukeys' $B$ post hoct test. Having a difference in the decrease in blood glucose levels between the positive control group and the five doses of meniran extract and rosella gave a significant effect compared to the negative control group did not have a significant effect in reducing blood glucose levels. Conclusion: Single meniran extract and high-dose combination extract are more effective than glibenclamide.
\end{abstract}

Keywords : Meniran leaf extract, Rosella extract, Diabetes mellitus, Alloxan

\section{PENDAHUluaN}

Obat tradisional adalah bahan-bahan yang terdiri dari ramuan dari tumbuhan, mineralmineral, sediaan sari-sarian (galenik), atau campuran dari bermacam-macam bahan tersebut dan secara turun-temurun telah digunakan untuk pengobatan yang diterapkan sesuai dengan norma yang berlaku di masyarakat (Hendra, 2018). Salah satu penyakit yang sering diobati dengan obatobatan tradisional adalah Diabetes Melitus. Diabetes Melitus (DM) merupakan suatu penyakit yang ditandai dengan kadar glukosa darah (gula darah) melebihi ambang normal, yaitu kadar gula darah sewaktu sama atau lebih dari $200 \mathrm{mg} / \mathrm{dl}$, dan kadar gula darah puasa di atas atau sama dengan $126 \mathrm{mg} / \mathrm{dl}$ (Misnadiarly, 2006). Secara epidemiologi, pada tahun 2030 prevalensi Diabetes Melitus (DM) di Indonesia diperkirakan mencapai 21,3 juta orang, sedangkan menurut hasil Riset kesehatan Dasar (Riskesdas) pada tahun 2007 proporsi penyebab kematian akibat DM pada kelompok usia 45 s/d 54 tahun di daerah perkotaan menduduki ranking ke-2 yaitu sebesar $14,7 \%$, sementara itu di daerah pedesaan, DM menduduki ranking ke-6 yaitu sebesar 5,8\% (Kementrian Kesehatan Republik Indonesia, 2009). Salah satu tumbuhan ditemukan mempunyai khasiat sebagai obat adalah rosella (Hibiscus Sabdariffa L.) yang mempunyai khasiat yaitu untuk menyembuhkan batuk, mencegah penyakit kanker, mengobati sariawan, menjaga kesehatan pembentukan tulang, menghaluskan kulit wajah, juga mempunyai khasiat untuk menyembuhkan kencing manis (Wulandari, 2016). Penelitian secara in vivo dan in vitro menyatakan bahwa ekstrak bunga rosella (Hibiscus sabdariffa L.) memiliki aktivitas antioksidan yang tinggi (Da Costacet al, 2014). Zat-zat aktif dalam kelopak bunga rosella antara lain gossypetin, antosianin, dan glukosida hibisci (Moeksin \& Ronald, 2009). Warna merah pada bunga rosella (Hibiscus Sabdariffa L.) disebabkan karenan adanya kandungan antosianin. Antosianin berfungsi sebagai antioksidan yang diyakini dapat 


\begin{tabular}{c|c|c}
\hline Jurnal Penelitian Farmasi Herbal & Vol. 2 No. 1 & Edition: May - October 2019 \\
\hline \multirow{2}{*}{ Received: 26 October 2019} & http://ejournal.delihusada.ac.id/index.php/JPFH & Accepted: 31 October 2019 \\
\cline { 2 - 3 } & Revised: 30 October 2019 &
\end{tabular}

menyembuhkan penyakit degenerative (Mardiah, 2010).

Selain kelopak bunga rosella (Hibiscus sabdariffa L), meniran (Phyllantus niruri L.) juga merupakan salah satu tanaman yang telah banyak dilaporkan memiliki efek sebagai imunostimulan atau mampu meningkatkan sistem imun tubuh, bahkan telah digunakan sebagai salah satu penyusun dari sediaan fitofarmaka yang beredar dimasyarakat, yang berkhasiat sebagai: pembangun stamina tubuh, penurun tekanan darah, penurun gula darah, penghilang asam urat, disentri, sakit gigi, demam, dan TBC (Dewi, 2015). Zat yang terkandung dalam meniran antara lain adalah flavonoid, filantin, hipofilantin, damar dan tanin dipercaya berkhasiat sebagai diuretik, antioksidan, antiinflamasi, antidiabetes, antipiretik dan penambah nafsu makan (Nugrahani, 2013). Dalam sebuah penelitian eksperimental tahun 2017, diketahui bahwa pemberian ekstrak daun meniran dengan dosis $5,0 \mathrm{mg} / \mathrm{kg}$ bb/hari dapat memperbaiki kerusakan sel- $\beta$ pankreas dan menurunkan kadar glukosa darah (Wahjuni, 2017).

Berdasarkan latar belakang tersebut, penulis berinisiatif untuk melakukan penelitian tentang efektivitas penyembuhan antidiabetes menggunakan ekstrak etanol daun meniran (Phyllanthus niruri L.) dan kelopak bunga rosella (Hibiscus sabdariffa L.) pada tikus dan penulis berharap penelitian sebelumnya dapat mendukung data ilmiah lainnya dalam penggunaan dan pemanfaatan daun meniran dan kelopak bunga rosella sebagai obat tradisional.

\section{METODE}

Jenis penelitian ini adalah penelitian eksperimental yang hasilnya diuraikan menggunakan metode penelitian kualitatif.

\section{Alat dan Bahan}

Alat yang digunakan dalam pelaksanaan penelitian ini adalah: Beaker glass $250 \mathrm{ml}$ (Pyrex), beaker glass $100 \mathrm{ml}$ (Pyrex), batang pengaduk, cawan penguap, corong (Pyrex), erlenmeyer 250 $\mathrm{ml}$ (Aprox), erlemenyer $100 \mathrm{ml}$ (Aprox), gelas ukur $1000 \mathrm{ml}$ (Pyrex), gelas ukur $100 \mathrm{ml}$ (Pyrex), gelas ukur $10 \mathrm{ml}$ (Pyrex), glukometer, hot plate (Arec), kertas saring, kandang hewan uji, rotary evaporator (Heidolp), oral sonde, strip glukometer, spuit $1 \mathrm{ml}$, spuit $2 \mathrm{ml}$, spuit $3 \mathrm{ml}$, stopwatch, thermometer, timbangan analitik, dan timbangan hewan uji.

Hewan uji: Tikus jantan putih dengan usia 2 s/d 3 bulan dan berat 100-200 gram. Bahan uji: Daun meniran (Phyllanthus nururi L.) dan kelopak bungan rosella (Hibiscus sabdariffa L.).

Senyawa pembanding: Glibenklamid $5 \mathrm{mg}$. Pereaksi: etanol $80 \%$, CMC Na $1 \%$, dan aquadest, amil alkohol, asam asetat, asam klorida, asam sulfat, besi (III), buffer sitrat, nheksan, pereaksi mayer, pereaksi bouchardat, peraksi dragendorff, klorida dan aloksan.

\section{Uji Efektivitas Antidiabetik}

Sebelum pengujian, tikus dipuasakan selam 8 jam (tidak makan tetapi masih tetap diberi minum). Hewan dikelompokkan kedalam 7 kelompok, yang masing- masing kelompok terdiri dari 3 ekor tikus, yaitu:

- Kelompok I: Kontrol positif suspensi glibenklamid dosi 0,45 mg/kgBB. Kelompok II: Kontrol negatif suspensi CMC Na $1 \%$.

- Kelompok III: Suspensi ekstrak daun meniran tunggal dosis $200 \mathrm{mg} / \mathrm{kgBB}$. Kelompok IV: Suspensi ekstrak tunggall rosella dosis 130 $\mathrm{mg} / \mathrm{kgBB}$. Kelompok V: Suspensi ekstrak kombinasi daun meniran dosis $100 \mathrm{mg} / \mathrm{kgBB}$ dan ekstrak rosella dosis $65 \mathrm{mg} / \mathrm{kgBB}$.

- Kelompok VI: Suspensi ekstrak kombinasi daun meniran dosis $200 \mathrm{mg} / \mathrm{kgBB}$ dan ekstrak rosella dosis $130 \mathrm{mg} / \mathrm{kgBB}$.

- Kelompok VII: Suspensi ekstrak kombinasi dosis $400 \mathrm{mg} / \mathrm{kgBB}$ dan ekstrak rosella dosis $400 \mathrm{mg} / \mathrm{kgBB}$. Langkah selanjutnya tikus diinduksi dengan aloksa dengan dosis 125 $\mathrm{mg} / \mathrm{kgBB}$ yang diberikan secara intraperitoneal. Setelah itu tikus diberi makan dan minum seperti biasa. Kadar glukosa darah diperiksa kembali pada post aloksan 3 jam dan post aloksan 6 hari.

Semua hewan uji yang telah diinduksi dengan aloksan selama 3 hari dipuasakan kembali selama 8 jam sebelum diberi perlakuan. Setelah tikus dipuasakan, periksa kembali kadar glukosa tikus. Kemudian tikus diberi larutan uji sekali sehari diberikan secara oral selanjutnya diukur kembali kadar glukosa darahnya pada hari pertama sampai hari keenam. Semua sampel darah diambil 


\begin{tabular}{l|r|r}
\hline Jurnal Penelitian Farmasi Herbal & Vol. 2 No. 1 & Edition: May - October 2019 \\
\hline \multirow{2}{*}{ Received: 26 October 2019} & http://ejournal.delihusada.ac.id/index.php/JPFH & Accepted: 31 October 2019 \\
\cline { 2 - 3 } & Revised: 30 October 2019 &
\end{tabular}

dari vena ekor tikus dan kadar glukosa darah diukur dengan glukometer Easy Touch.

\section{HASIL DAN PEMBAHASAN}

Pada penelitian ini bahan yang digunakan untuk membuat simplisia adalah daun meniran dan kelopak bunga rosella. Dibawah ini merupakan hasil skrining fitokimia serbuk simplisia dari daun meniran dan kelopak bunga rosella.

Tabel 1. Hasil skrining fitokimia serbuk simplisia daun meniran

\begin{tabular}{|l|c|}
\hline \multicolumn{1}{|c|}{ Golongan Senyawa } & Hasil \\
\hline Flavonoid & + \\
\hline Tanin & + \\
\hline Saponin & - \\
\hline Alkaloid & + \\
\hline Steroid & - \\
\hline Glikosida & - \\
\hline Glikosida Antrakuinon & - \\
\hline
\end{tabular}

Tabel 2. Hasil skrining fitokimia serbuk simplisia kelopak bunga rosella

\begin{tabular}{|l|c|}
\hline \multicolumn{1}{|c|}{ Golongan Senyawa } & Hasil \\
\hline Flavonoid & + \\
\hline Tanin & + \\
\hline Saponin & + \\
\hline Alkaloid & + \\
\hline Steroid & - \\
\hline Glikosida & - \\
\hline Glikosida Antrakuinon & - \\
\hline
\end{tabular}

\section{Hasil induksi aloksan}

Penelitian ini mengguna 21 ekor tikus yang dibagi menjadi 7 kelompok. Sebelum semua hewan uji diberi perlakuan, terlebih dahulu dilakukan penginduksian menggunakan aloksan dengan dosis $125 \mathrm{mg} / \mathrm{kgBB}$ secara intraperitonial (Prameswari \& Qodarian, 2014). Penginduksian ini dilakukan untuk mendapatkan hewan uji yang hiperglikemik. Proses penginduksian ini dilakukan selama 3 hari. Kadar glukosa darah hewan uji diatas $200 \mathrm{mg} / \mathrm{dL}$ maka hewan uji dianggap mengalami diabetes.

\section{Hasil uji efektivitas}

Uji efektivitas antidiabetes dilakukan pada tikus jantan putih. Dimana tikus dibagi menjadi 7 kelompok perlakuan. Setiap perlakuan terdiri dari 3 ekor tikus. Tikus yang digunakan pada penelitian ini adalah tikus putih jantan galur wistar. Menurut
Ainii (2017), tikus putih berjenis kelamin jantan dapat memberikan hasil penelitian yang lebih stabil karena tidak dipengaruhi oleh siklus menstruasi dan kehamilan seperti pada tikus betina. Tikus putih berjenis kelamin jantan mempunyai kecepatan metabolisme yang lebih cepat dan kondisi biologis tubuh yang lebih stabil bila dibandingkan tikus betina. Sebelum diberi perlakuan, semua kelompok tikus diinduksi terlebih dahulu dengan menggunakan aloksan dosis $125 \mathrm{mg} / \mathrm{kgBB}$ selama 3 hari (Prameswari, 2014).

Hewan uji yang akan diberi perlakuan dipuasakan selama 8 jam dan ditimbang kembali berat badan tikus pada masing-masing kelompok. Setelah itu diperiksa kadar glukosa darah awal. Kadar glukosa darah hari terakhir penginduksian aloksan merupakan kadar glukosa darah awal pada penelitian ini. Uji efektivitas antidiabetes dilakukan selama 6 hari. Selanjutnya sebelum diberi perlakuan, semua kelompok tikus diinduksi terlebih dahulu dengan menggunakan aloksan dengan dosis $125 \mathrm{mg} / \mathrm{kgBB}$ selama 3 hari (Prameswari, 2014). Hewan uji yang akan diberi perlakuan dipuasakan selama 8 jam dan ditimbang kembali berat badan tikus pada masing-masing kelompok. Setelah itu diperiksa kadar glukosa darah awal. Kadar glukosa darah hari terakhir penginduksian aloksan merupakan kadar glukosa darah awal pada penelitian ini. Uji efektivitas antidiabetes dilakukan selama 6 hari.

Analisis statistik yang pertama dilakukan adalah untuk menentukan uji normalitas yang dilihat adalah Shapiro-Wilk adalah karena data yang dianalisis hanya 21 data. Uji distribusi data Shapiro-Wilk pada kadar glukosa darah CMC Na $p=0,2988$, glibenklamid $p=0,780$, rosella tunggal $p=0,363$, meniran tunggal $p=0,1000$, kombinasi dosiss rendah $p=0,843$, Kombinasi dosis sedang $p=0,780$, kombinasi dosis tinggi $p=0,510$ apabila $\mathrm{p}>0,05$ maka dapat disimpulkan bahwa data terdistribusi normal sehingga pada kadar glukosa darah $\mathrm{H} 6$ distribusi datanya normal.

Uji statistik yang kedua adalah test of homogenity of variance. Uji data ini levene test pada ketujuh kelompok perlakuan, hasilnya pada penurunan kadar glukosa darah hari ke- 6 yaitu setelah pemberian aloksan adalah $\mathrm{p}=0,0434$. 


\begin{tabular}{l|c|c}
\hline Jurnal Penelitian Farmasi Herbal & Vol. 2 No. 1 & Edition: May - October 2019 \\
\hline \multirow{2}{*}{ Received: 26 October 2019} & http://ejournal.delihusada.ac.id/index.php/JPFH & Accepted: 31 October 2019 \\
\cline { 2 - 3 } & Revised: 30 October 2019 &
\end{tabular}

Pada analisis menggunakan levene test ini datanya dikatakan homogen jika menunjukkan nilai $p>0,05$ dari data diatas maka dapat disimpulkan bahwa data diatas homogen.

Selanjutnya uji post hoct test. Uji post hoct test yang dilakukan adalah uji LSD dan uji Tukeys-B. Uji tukeys-B adalah uji yang dilakukan untuk melihat dosis yang paling efektif atau signifikan dalam menurunkan kadar glukosa darah tikus yang diinduksi aloksan $125 \mathrm{mg} / \mathrm{kgBB}$ dengan melihat nilai yang terkecil disetiap perlakuan. Dosis yang paling efektif dalam menurunkan glukosa darah yang diinduksi aloksan $125 \mathrm{mg} / \mathrm{kgBB}$ yaitu meniran tunggal 90.00, kombinasi dosis tinggi 110.67, glibenklamid 116.67, kombinasi dosis rendah 122.33, kombinasi dosis sedang 124.33 , rosella tunggal 126.00, CMC Na 341.33.

Uji LSD yang dilakukan pada tiap kelompok perlakuan untuk membandingkan perbedaan ratarata anatr kelompok perlakuan pada uji LSD apabila nilai $p>0,05$ berbeda tidak signifikan yang artinya tidak terdapat perbedaan efek penurunan kadar glukosa darah tikus. Hasil uji LSD yang diperoleh $\mathrm{CMC} \mathrm{Na}$ dengan glibenklamid, rosella tunggal, meniran tunggal, kombinasi dosis rendah, kombinasi dosis sedang dan kombinasi dosis tinggi $p<0,05$. Glibenklamid dengan CMC $\mathrm{Na}$, kelopak bunga rosella tunggal, daun meniran tunggal, kombinasi dosis rendah, kombinasi dosis sedang dan kombinasi dosis tinggi $p>0,05$. Rosella tunggal dengan CMC Na, glibenklamid, meniran tunggal, kombinasi dosis rendah, kombinasi dosis sedang, dan kombinasi dosis tinggi $\mathrm{p}>0,05$. Meniran tunggal dengan $\mathrm{CMC} \mathrm{Na}$, glibenklamid, kelopak bunga rosella tunggal, daun meniran tunggal, kombinasi dosis rendah, kombinasi dosis sedang, dan kombinasi dosis tinggi $p<0,05$.

Kombinasi dosis rendah dengan $\mathrm{CMC} \mathrm{Na}$, glibenklamid, kelopak bunga rosella tunggal, daun meniran tunggal, kombinasi dosis rendah, kombinasi dosis sedang dan kombinasi dosis tinggi $p>0,05$. Kombinasi dosis sedang dengan CMC Na, glibenklamid, kelopak bunga rosella tunggal, daun meniran tunggal, kombinasi dosis rendah, kombinasi dosis sedang dan kombinasi dosis tinggi $p>0,05$. Kombinasi dosis sedang dengan CMC Na, glibenklamid, rosella tunggal, meniran tunggal, kombinasi dosis rendah, kombinasi dosis sedang dan kombinasi dosis tinggi $p>0,05$. Kombinasi dosis tinggi dengan CMC $\mathrm{Na}$, glibenklamid, rosella tunggal, meniran tunggal, kombinasi dosis rendah, kombinasi dosis sedang, dan kombinasi dosis tinggi $p<0,05$.

\section{KESIMPULAN}

Dari hasil penelitian yang telah dilakukan dapat disimpulkan, ekstrak daun meniran (Phyllanthus niruri L.) memiliki efek antidiabetes yang sangat efektif. Selain itu, kombinasi ekstrak daun meniran (Phyllanthus niruri L.) dan kombinasi ekstrak daun meniran (Phyllanthus niruri L.) dan ekstrak kelopak bunga rosella (Hibiscus sabdariffa L.) dosis tinggi memiliki efek yang lebih baik bila dibandingkan dengan sediaan obat glibenklamid dosis $0,45 \mathrm{mg} / \mathrm{kgBB}$.

\section{DAFTAR PUSTAKA}

Aini, Q., Sabri, M., \& Samingan. (2015). Pemberian Ekstrak Daun Kelor Terhadap Kadar Glukosa Darah Pada Tikus Jantan Yang Dinduksi Aloksan. Banda Aceh: Edubio Tropika, Vol. 3. 2339-2649.

Da-Costa-Rocha,I., Bonnlaender, B., Sievers, H., Pischel, I., \& Heinrich, M. (2014). Hibiscus sabdariffa L. - A phytochemical and pharmacological review. 165 (Food Chemistry).

Dewi. (2015). Uji Aktivitas Antidiabetes Ekstrak Air Kelopak Bunga Rosella Pada Tikus Dengan Metode Induksi Aloksan. Jember: Fakultas Farmasi Universitas Jember.

Hendra. (2018). Penatalaksanaan Diabetes Mellitus Terpadu. Jakarta: Balai Penerbit FKUI.

Kementrian Kesehatan Republik Indonesia. (2009). Tahun 2030 Prevalensi Diabetes Melitus di Indonesia Mencapai 21,3 Juta Orang. Retrieved agustus 5, 2019, from www.kemkes.go.id.

Mardiah, Amalia, L., \& Sulaeman, A. (2010). Ekstraksi Kulit Batang Rosella (Hibiscus sabdarifffa L.) Sebagai Pewarna Merah Alami . Jurnal Pertanian Vol. 1. 2087-4936.

Misnadiarly. (2006). Diabetes Mellitus, Mengenali Gejala, Menanggulangi, Mencegah Komplikasi. Jakarta: Pustaka Populer Obor.

Moeksin, R., \& Ronald, S. (2009). Pengaruh Kondisi, Perlakuan dan Berat Sampel Terhadap Ekstraksi Antosianin dari Kelopak 


\begin{tabular}{l|c|c}
\hline Jurnal Penelitian Farmasi Herbal & Vol. 2 No. 1 & Edition: May- October 2019 \\
\hline & http://ejournal.delihusada.ac.id/index.php/JPFH & Accepted: 31 October 2019 \\
\hline Received: 26 October 2019 & Revised: 30 October 2019 & \\
\hline $\begin{array}{l}\text { Bunga Rosella dengan Pelarut Aquadest } \\
\text { dan Etanol. Jurnal Teknik Kimia, Vol. 16. }\end{array}$
\end{tabular}

Prameswari, \& Qodarian. (2014). Uji Efek ekstrak Daun Pandan Wangi Terhadap Penurunan Kadar Glukosa Darah dan Histopatologi Tikus Diebetes Melitus. Malang: Universitas Brawijaya.

Nugrahani, S, S. (2013). Analisis Perbandingan Efektivitas EKstrak Akar, Batang dan Daun Herba Meniran dalam menurunkan kadar glukosa darah mencit. Unnes Journal of Public Health, Vol. 2.

Wahjuni, S. (2017). Ekstrak Daun Meniran (Phyllantus niruri L.) memperbaiki Kerusakan sel B-pankreas dan menurunkan kadar gula darah tikus wistar hiperglikemia diinduksi aloksan . Intisari Sains Media, Vol. 8.

Wulandari. (2016). Aneka Manfaat Bunga Untuk Kesehatan . Jakarta. 